\title{
Correction to: The association between crop and income diversity and farmer intra-household dietary diversity in India
}

\author{
Sukhwinder Singh ${ }^{1}$ (D) $\cdot$ Andrew D. Jones ${ }^{2} \cdot$ Ruth S. DeFries $^{3} \cdot$ Meha Jain $^{1}$
}

Published online: 19 May 2021

(C) The Author(s) 2021

\section{Correction to: Food Security (2020) 12(2):369-390 https://doi.org/10.1007/s12571-020-01012-3}

The article "The association between crop and income diversity and farmer intra-household dietary diversity in India", written by Sukhwinder Singh, Andrew D. Jones, Ruth S. DeFries, and Meha Jain, was originally published Online First without Open Access. After publication in volume 12 , issue 2 , page 369-390 the author decided to opt for Open Choice and to make the article an Open Access publication. Therefore, the copyright of the article has been changed to (C) The Authors 2021 and the article is forthwith distributed under the terms of the Creative Commons Attribution 4.0 International License, which permits use, sharing, adaptation, distribution and reproduction in any medium or format, as long as you give appropriate credit to the original author(s) and the source, provide a link to the Creative Commons licence, and indicate if changes were made. The images or other third party

The online version of the original article can be found at https://oi.org/ 10.1007/s12571-020-01012-3

Sukhwinder Singh

sukhrec@yahoo.com

Andrew D. Jones

jonesand@umich.edu

Ruth S. DeFries

rd2402@columbia.edu

Meha Jain

mehajain@umich.edu

1 School for Environmental and Sustainability (SEAS), University of Michigan, Ann Arbor, MI 48109, USA

2 School of Public Health, University of Michigan, Ann Arbor, MI 48109, USA

3 Department of Ecology, Evolution, and Environmental Biology (E3B), Columbia University, New York, NY 10027, USA material in this article are included in the article's Creative Commons licence, unless indicated otherwise in a credit line to the material. If material is not included in the article's Creative Commons licence and your intended use is not permitted by statutory regulation or exceeds the permitted use, you will need to obtain permission directly from the copyright holder. To view a copy of this licence, visit http://creativecommons.org/licenses/by/4.0/.

The original article has been corrected.

Open Access This article is licensed under a Creative Commons Attribution 4.0 International License, which permits use, sharing, adaptation, distribution and reproduction in any medium or format, as long as you give appropriate credit to the original author(s) and the source, provide a link to the Creative Commons licence, and indicate if changes were made. The images or other third party material in this article are included in the article's Creative Commons licence, unless indicated otherwise in a credit line to the material. If material is not included in the article's Creative Commons licence and your intended use is not permitted by statutory regulation or exceeds the permitted use, you will need to obtain permission directly from the copyright holder. To view a copy of this licence, visit http://creativecommons.org/licenses/by/4.0/. 